\title{
Range fragmentation in the spectacled bear Tremarctos ornatus in the northern Andes
}

\author{
Gustavo Kattan, Olga Lucía Hernández, Isaac Goldstein, Vladimir Rojas, Oscar Murillo, Carolina Gómez, \\ Héctor Restrepo and Francisco Cuesta
}

\begin{abstract}
This paper addresses the conservation status of the spectacled bear Tremarctos ornatus in the northern Andes (Venezuela, Colombia and Ecuador) by analysing the degree of range fragmentation and estimating habitat availability. From satellite images we constructed maps of remnant habitat blocks, consisting of Andean forest and páramo (high elevation shrublands and grassland) ecosystems. This information was overlain with a road map to determine potential isolation of populations, and a human accessibility model was used to estimate the core area of each block. This analysis revealed that the species' range is fragmented by landscape transformation and roads into 113 blocks $>100 \mathrm{~km}^{2}$, representing $42 \%$ of the original extent of the bear's distribution. Forty percent of the blocks are $<500 \mathrm{~km}^{2}$, and only nine are $>5,000 \mathrm{~km}^{2}$. However, taking into account only core area, $56 \%$ of the blocks are $<500 \mathrm{~km}^{2}$ and only six are $>5,000 \mathrm{~km}^{2}$. In addition, many blocks have internal patches of colonization, further reducing habitat quality.
\end{abstract}

This effect is more severe in smaller fragments, where internal disturbances constitute a high proportion of the block area. We used a high population density estimate of 0.25 , a medium density of 0.11 and a low density of 0.04 bears per $\mathrm{km}^{2}$ to estimate population sizes. Twentynine populations are likely to have $>500$ individuals with the high estimate, but only nine with the medium and one with the low estimate (largest estimated population was 9,048 bears). These estimates are much lower if only the core area of blocks is used. Hunting has been identified as a major threat for many bear populations. Our analyses indicate that a regional conservation strategy for spectacled bear should focus on maintaining or increasing habitat availability in larger blocks, and reducing human-induced mortality across the region.

Keywords Density, habitat availability, habitat fragmentation, northern Andes, spectacled bear, Tremarctos ornatus.

\section{Introduction}

The spectacled or Andean bear Tremarctos ornatus is the only extant representative of the Ursidae in South America. Its geographic distribution extends along the tropical Andes from Venezuela to the Bolivia-Argentina border. Covering 38 degrees of latitude $\left(11^{\circ} \mathrm{N}\right.$ to $\left.27^{\circ} \mathrm{S}\right)$,

Gustavo Kattan (Corresponding author), Vladimir Rojas and Carolina Gómez Wildlife Conservation Society, Colombia Program, Apartado 25527, Cali, Colombia. E-mail gkattan@wcs.org

Olga Lucía Hernández World Wildlife Fund-Colombia, Carrera 35 No. 4A-25, Cali, Colombia.

Isaac Goldstein Wildlife Conservation Society, Venezuela Program, Mérida, Venezuela.

Oscar Murillo Departamento de Biología, Universidad del Valle, Cali, Colombia.

Héctor Restrepo Unidad de Parques Nacionales Seccional Noroccidental, Medellín, Colombia.

Francisco Cuesta Fundación EcoCiencia, Manuel Sáenz E 14-34, Quito, Ecuador.

Received 17 June 2003. Revision requested 3 September 2003. Accepted 24 November 2003. this elongated and narrow range is only $200-650 \mathrm{~km}$ wide but more than $4,600 \mathrm{~km}$ long. Throughout this range spectacled bears occupy a variety of ecosystems, from dry areas in the coastal range of Perú to humid cloud forest and páramo (a high elevation grassland and shrubland ecosystem) in the northern Andes. The geographic range of the spectacled bear coincides with some areas of high human population density, particularly in the northern Andes (Venezuela to Ecuador). Consequently, it faces various threats related to human presence, particularly habitat degradation and destruction, fragmentation of populations, and hunting. The spectacled bear is categorized as Vulnerable on the IUCN Red List (Peyton, 1999; IUCN, 2003).

Peyton et al. (1998) identified large habitat blocks (i.e. blocks of unbroken Andean forest) occupied by the spectacled bear throughout its range, and estimated an area of occupancy of about $260,000 \mathrm{~km}^{2}$. Assuming population densities similar to American black bears Ursus americanus, the total spectacled bear population was estimated at $>20,000$ adult individuals (Peyton et al., 1998). This population, however, is subdivided into many smaller units, and long-term viability of the global 
population depends on the degree of isolation and viability of individual subpopulations. The range of the spectacled bear is most fragmented in the northern half of its distribution, in Venezuela, Colombia and Ecuador (Peyton et al., 1998). This fragmentation entails several problems. Firstly, if populations are isolated and relatively small, their persistence is compromised, even in the absence of hunting and further habitat loss. Secondly, landscape transformation in the region changes the availability of the habitat types required by bears. Spectacled bears perform regional movements, using different habitat types along altitudinal gradients, but the seasonal patterns of these movements are not well known. Fragmentation disrupts these movements and restricts access to seasonally required habitats. Thirdly, fragmentation exposes bears to hunting. The smaller and more accessible the fragment, the higher the probability that the bears will move across the fragment's boundary and into farms (Woodroffe \& Ginsberg, 1998), exposing them to being killed.

Peyton et al. (1998) evaluated the protection status of bear populations throughout the Andes by estimating the amount of potential bear habitat included in national parks. They estimated that c. $18.5 \%$ of the bear's actual range is contained within 58 protected areas. Many of these areas, however, are small, particularly in the northern Andes. Median size of 43 parks in Venezuela, Colombia and Ecuador is $1,250 \mathrm{~km}^{2}$, which may be insufficient to maintain a viable population of bears (Peyton et al., 1998). The largest protected area of bear habitat in this region is $2,050 \mathrm{~km}^{2}$. The viability of populations in these parks depends on their degree of isolation and availability of habitat outside protected areas, which may be considerable in some cases. These unprotected habitat blocks may provide potential opportunities for protection of bear populations. Here we present an evaluation of potential habitat availability and range fragmentation of the spectacled bear in the northern Andes. Using satellite images we mapped blocks of habitat potentially occupied by bears in the region. Then, by overlaying information on land use cover and roads, we evaluated the degree of isolation of populations and the accessibility of the areas to humans. This analysis provides an overview of the status of bear populations in the region, and can be used to help focus a conservation strategy for this species.

\section{Methods}

The basis of our analysis was a map of present vegetation and land use cover produced for the WWF-sponsored Northern Andes Ecoregional Complex project, which developed a biodiversity vision for the region (Kattan, 2000; WWF, 2000). The northern Andes are defined as the
Andes north of the Huancabamba Depression in northern Perú, close to the Ecuadorian border. This depression is a natural break that bisects the Andes and defines two biogeographical regions (the northern and southern Andes; Duellman, 1999), and represents the southern limit of the páramo. The vegetation and land use cover map was derived from a composite of satellite images (LANDSAT TM5 and TM7 for 1994-2000) that were interpreted with the ER Mapper software (Earth Resource Mapping, San Diego, California, USA). The lower elevation limit was set at $500 \mathrm{~m}$. For this paper we mapped three types of cover: remnant montane forest vegetation, páramo, and transformed habitat. This last category included all anthropogenic habitats such as pasturelands, croplands and urban areas. All types of Andean forest between elevations of $500 \mathrm{~m}$ and the forest-páramo ecotone (the treeline) were considered appropriate bear habitat (present knowledge of patterns of habitat use does not permit a finer discrimination of bear habitat quality). Analyses were made using ArcView GIS (ESRI, Redlands, California, USA) in a grid format with a $1 * 1 \mathrm{~km}$ cell resolution.

On the vegetation map we overlaid the road network, obtained from government cartography. Roads were classified in two categories, main and secondary. Main roads belong to the national road networks that connect major cities; these roads are paved, support heavy traffic, and cross highly transformed landscapes. Secondary roads belong to provincial networks in rural areas, are frequently unpaved, and some cut through forest and páramo landscapes. A buffer of $2.5 \mathrm{~km}$ was established around main roads, and $1 \mathrm{~km}$ around secondary roads (an impact band of at least $2 \mathrm{~km}$ has been established for spectacled bears (Peyton, 1999). Then, we recalculated polygon areas and fragments of $<100 \mathrm{~km}^{2}$ were eliminated. To evaluate accessibility of the areas, we used a model developed by the International Centre for Tropical Agriculture, Cali, Colombia, which is based on the time it takes to reach different points on the map, measured in hours from the nearest road or populated place; the model takes into account various parameters, including topography and availability of transportation. Accessibility in this model is classified into four categories: 1-6 hours (category 1, highly accessible), 7-24 hours (category 2, accessible), 25-60 hours (category 3, low accessibility) and $>60$ hours (category 4 , inaccessible). For our analysis we pooled together categories 1 and 2 (accessible) and 3 and 4 (inaccessible). On the vegetation map, we assigned values of 1 or 0 to cells with or without natural forest or páramo cover, to indicate potential presence or absence of bears. Then, using Map Calculator (ArcView), we multiplied the vegetation grid and the accessibility grid to obtain accessibility values for cells in each habitat block. 
To estimate potential bear population sizes, we multiplied population densities by the surface area of the habitat blocks. As population density data are unavailable for the spectacled bear, we used data for other species of bear, assuming that ecological similarity justified extrapolation between species. To obtain a global spectacled bear population size, Peyton et al. (1998) used a low estimate of 0.07 individuals per $\mathrm{km}^{2}$, and a high value of 0.25 individuals per $\mathrm{km}^{2}$, based on American black bear data. Density estimates are, however, relatively variable among bear species, and even among populations of the same species. For example, densities of sloth bear Melursus ursinus in India vary between 0.01 and 1.24 individuals per $\mathrm{km}^{2}$, with a mean of 0.22 and a median of 0.12 bears per $\mathrm{km}^{2}$ (Garshelis et al., 1999). Yerena (1994) has proposed a low density estimate of 0.04 individuals per $\mathrm{km}^{2}$ and a high estimate of 0.11 individuals per $\mathrm{km}^{2}$ for spectacled bear in the Mérida Andes of Venezuela. However, recent evidence obtained in Ecuador and Venezuela suggests densities $>0.15$ individuals per $\mathrm{km}^{2}$ (I. Goldstein, pers. obs.). For this analysis we used the values suggested by Yerena ( 4 and 11 bears per $100 \mathrm{~km}^{2}$ ) to obtain low and medium estimates, and the value of 25 bears per $100 \mathrm{~km}^{2}$ used by Peyton et al. (1998) to obtain high estimates of population sizes.

\section{Results}

The map of remnant natural vegetation in the northern Andes revealed 113 discrete blocks of forest or combined forest/páramo habitat $>100 \mathrm{~km}^{2}$, separated by roads or transformed ecosystems (Fig. 1). These blocks represent potential bear habitat, and the occurrence of bears has been confirmed in most of them, as determined at an experts' workshop held in Riobamba, Ecuador, in November 2000. The total area of these blocks is $208,602 \mathrm{~km}^{2}$, representing $42 \%$ of the total area of the region (i.e. $490,000 \mathrm{~km}^{2}$, the presumed original extent of distribution of the Andean bear). Large habitat blocks encompassing a continuous elevational gradient remain in the Mérida range in Venezuela, in the Venezuelan (eastern) slope of the Serranía de Perijá (i.e. the northern end of the eastern branch of the Andes), and on the Pacific and Amazonian versants of the Colombian and Ecuadorian Andes. Potential habitat in the inter-Andean versants of the Cauca and Magdalena valleys in Colombia is restricted to the upper elevations of the Central Cordillera (Fig. 1). Forty percent of the potential habitat blocks are $<500 \mathrm{~km}^{2}$, especially in the inter-Andean slopes (Fig. 2). Only nine blocks have areas of $>5,000 \mathrm{~km}^{2}$.

Most of the potential bear habitats are totally surrounded by transformed ecosystems (except for some on the Pacific and eastern versants) and main and secondary roads cut through many of them (Fig. 3). Even the largest expanses of forest are bisected by roads, and thus the effective size of the habitat blocks is smaller than suggested by Fig. 1. Taking into account only the area of each habitat block that is classified as inaccessible, $56 \%$ of the blocks are $<500 \mathrm{~km}^{2}$, and only six are $>5,000 \mathrm{~km}^{2}$ (Fig. 2).

In addition, the internal quality of the areas for bears is variable. Most areas have some degree of internal disturbance caused by foci of human colonization (Fig. 4). The effect of this type of disturbance is more important in small areas, as a large proportion of the area may be affected, further reducing its suitability as bear habitat. Spectacled bears probably use forests at different altitudes in different proportions and in different seasons, and therefore the altitudinal extent of forest cover will also affect habitat quality. We did not distinguish forest types, but most of the areas have some amount of forest habitat between 1,000 and 3,000 $\mathrm{m}$ (i.e. the ideal altitudinal extent of forested habitat for bears), although in the inter-Andean valleys of Colombia and Ecuador the lower elevations are highly transformed and forest remains only at the upper elevations $(>2,000 \mathrm{~m})$. Proportional availability of forest and páramo also varied among areas (Fig. 4). Some areas on the Pacific slope have extensive forests but no páramo (páramo on the western range is small and scattered and does not show on Fig. 1 because of the scale of the map). Other areas on the other mountain ranges are totally isolated from páramo habitats, or conversely, most of the area is covered by páramo, with little cloud forest available (Figs. 1,4).

As expected from the size of the blocks, estimated population sizes for most areas were small (Fig. 5). Using the total area of the habitat block, and the high, medium and low density estimates, 36, 57 and 78 of the areas, respectively, are likely to have $<100$ individuals. Twenty-nine areas are likely to have $>500$ individuals with the high density estimate, but only nine with the medium and one with the low estimate (the largest estimated population is 9,048 bears, but all others are $<3,000$ bears). Estimated population sizes are much smaller if only the inaccessible core area is considered (Fig. 5). In this case, most populations have $<50$ bears, and only 17 have more than 500 individuals, with the high density estimate (the largest estimated population is $6,625$, but all others are $<2,200)$.

\section{Discussion}

The global pattern of decline of a species depends on how patterns of human disturbance interact with the size, shape and internal structure (i.e. spatial patterns of abundance) of its range. Even if the general boundary of the range does not change, extirpation of populations by habitat obliteration decreases the extent of occupancy of 


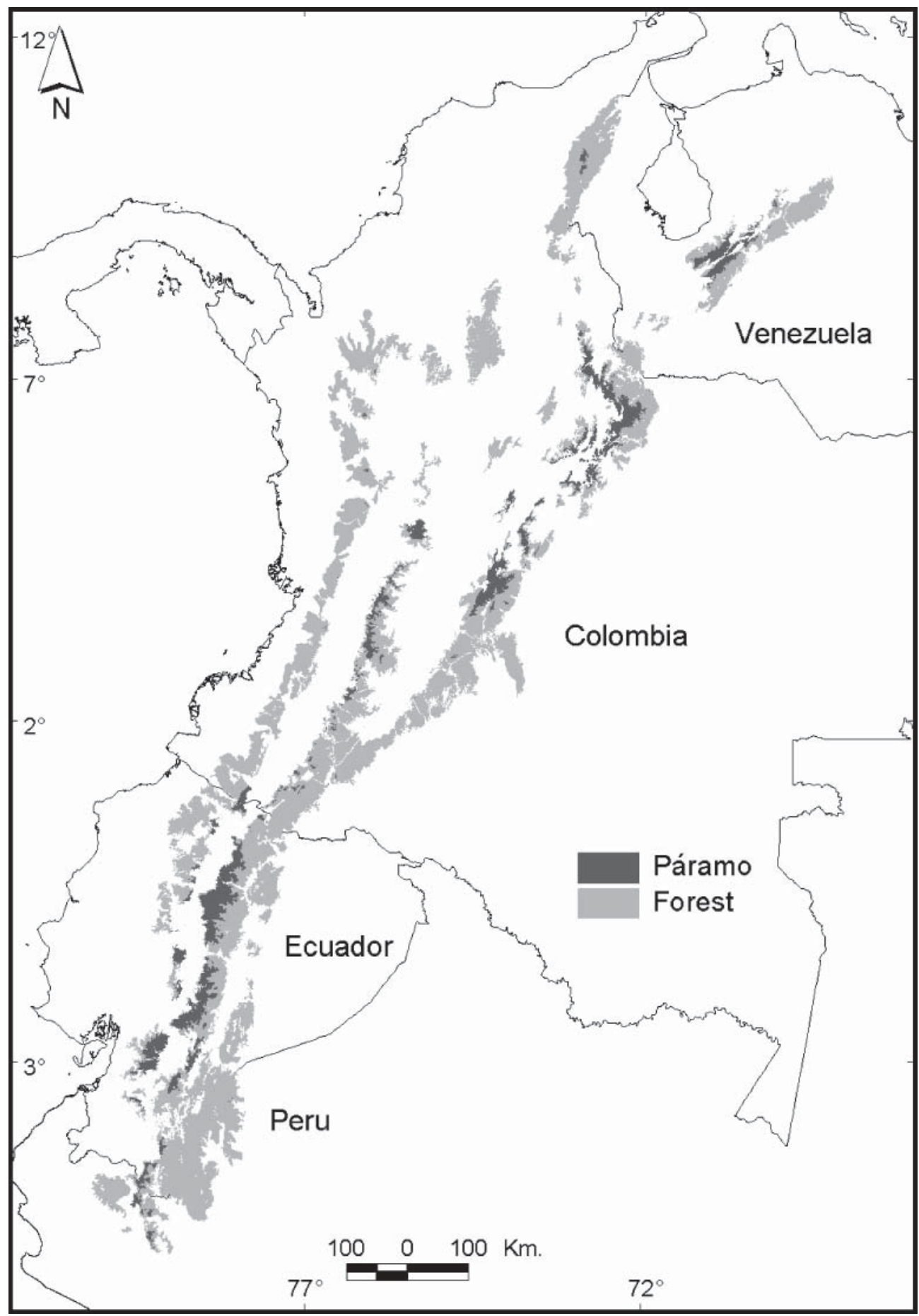

Fig. 1 The northern Andes, showing blocks of potential spectacled bear habitat in remnant cloud forest and páramo. Only blocks that are larger than $100 \mathrm{~km}^{2}$ are shown. White areas between habitat blocks represent transformed ecosystems. The lower limit of elevation for the delimitation of habitat is $500 \mathrm{~m}$.

the species and changes the internal structure of its range, causing fragmentation of populations. Assuming that the spectacled bear was originally distributed over the entire northern Andean region, including the inter-Andean valleys, its geographic range has contracted to $42 \%$ of the original area. Whether this represents a $58 \%$ contraction of the original population size depends on the original patterns of distribution and abundance, which are unknown. The degree of connectivity of remaining populations depends on the 


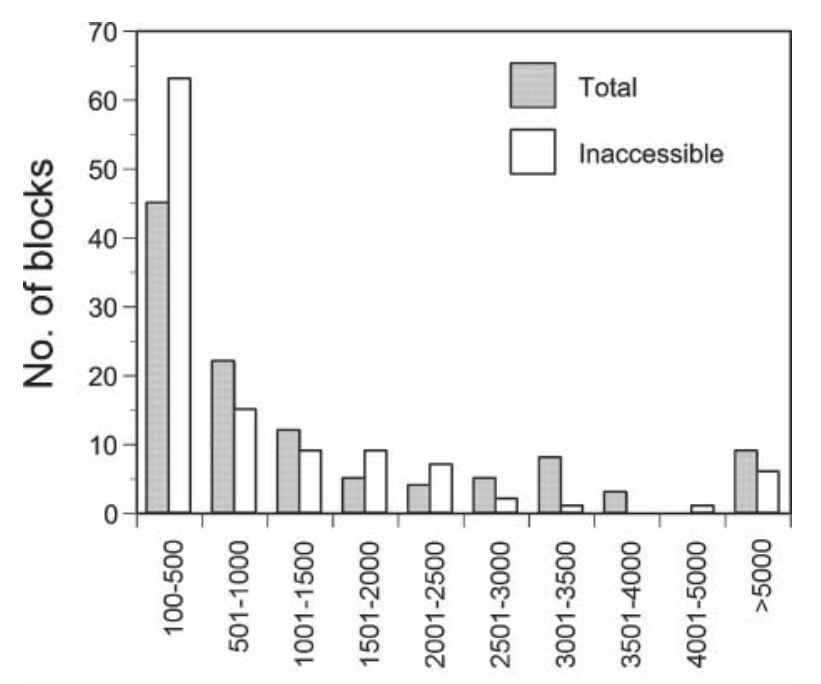

\section{Size of habitat block $\left(\mathrm{km}^{2}\right)$}

Fig. 2 Frequency distribution of number of bear habitat blocks in different size classes. Both total area of the block and inaccessible core area (see text for details) are shown.

pattern and distribution of human disturbance. The elongated shape of the spectacled bear's range and patterns of land use in the northern Andes make the range of this species particularly prone to fragmentation. As valleys and lower slopes are transformed, populations tend to be isolated at upper elevations. In addition, roads are built across mountain crests to connect valleys, thus bisecting remaining habitat blocks. Our analysis indicates that the bear's present range is fragmented into 113 units of potential habitat. Most of these habitat units are small (Fig. 2). Furthermore, it is possible that populations in these habitat blocks are isolated, because most of them are separated by roads and completely surrounded by anthropogenic habitats.

Roads might be an important barrier to bear movements and population connectivity. There is evidence that bears avoid roads, and that roads pose a mortality threat (Rodríguez, 1991; Powell et al., 1996; Pelton et al., 1999; Peyton, 1999). Another potential threat of roads is to increase human access to wild areas and the likelihood that bears will be killed. For wide-ranging species the interaction with people at reserve borders is a major source of mortality (Woodroffe \& Ginsberg, 1998). This threat is obviously exacerbated in small areas. Our analyses indicate that accessibility dramatically reduces the size of bear populations that would be free of human interference (Fig. 3).

We lack reliable estimates of population densities of spectacled bear in any part of its range. Using high, medium, and low density values suggested for spectacled bears, we estimate that most bear areas in Ecuador, Colombia and Venezuela have relatively small populations (Fig. 5). One factor that favours the population persistence of bears is, however, their longevity. If adult mortality is low, a long life span means that each female has a reasonable chance of raising at least two offspring to adulthood, sufficient for population replacement. It has been estimated for grizzly bears Ursus arctos in Montana that female annual survival rates of $>90 \%$ are, however, required to support population growth (Mace \& Waller, 1998).

Hunting, which may threaten small populations by decreasing survivorship rates, has been identified as a major factor limiting the viability of bear populations. For a grizzly bear population in Montana (Mace \& Waller, 1998) and an American black bear population in North Carolina (Powell et al., 1996), areas where there is human-caused mortality (legal or illegal) are population sinks. These populations persist because bears have access to refuges or areas of higher productivity that act as sources. For the spectacled bear, hunting is mainly the result of conflict with humans. As is typical of a landscape species, i.e. a species that require large home ranges to meet all their needs (Sanderson et al., 2002), bears move through a variety of habitat types and do not shy away from open areas. Thus, they are likely to raid crops in farms near or in forested areas. Recently, livestock predation by bears has been reported with increasing frequency in several areas in the northern Andes (Goldstein, 1992; D. Rodríguez \& J. Poveda, pers. comm.). This is a potential problem affecting the viability of bear populations in rural areas because of the killing of bears that it could instigate and the negative attitudes towards bears that it could generate.

Another problem for predicting the viability of spectacled bear populations is that the suitability of the different areas is likely to differ, depending on the proportional availability of different habitat types. These differences will translate into different population densities and demographic parameters (in addition to geographic variation caused by habitat productivity and other factors). Except for data for a few areas (Peyton, 1980, 1986; Rodríguez et al., 1986; Suárez, 1988; Rodríguez, 1991; Goldstein \& Salas, 1993), we have no precise information on the seasonal habitat and resource requirements of spectacled bears. Similar to other bears, spectacled bears consume a wide variety of plant and animal matter (Peyton, 1980; Rodríguez et al., 1986; Suárez, 1988; Goldstein \& Salas, 1993; Sandoval, 2000). The bulk of their diet, however, is composed of vegetable matter, including the meristematic tissues of bromeliads, palms and bamboos. Fruits are consumed opportunistically depending on their availability, and range from the aqueous, carbohydrate-rich fruits of Ficus spp, Cecropia spp and ericaceous shrubs, to the lipid-rich fruits of Lauraceae (Ocotea spp., Nectandra spp. and Persea spp.), 


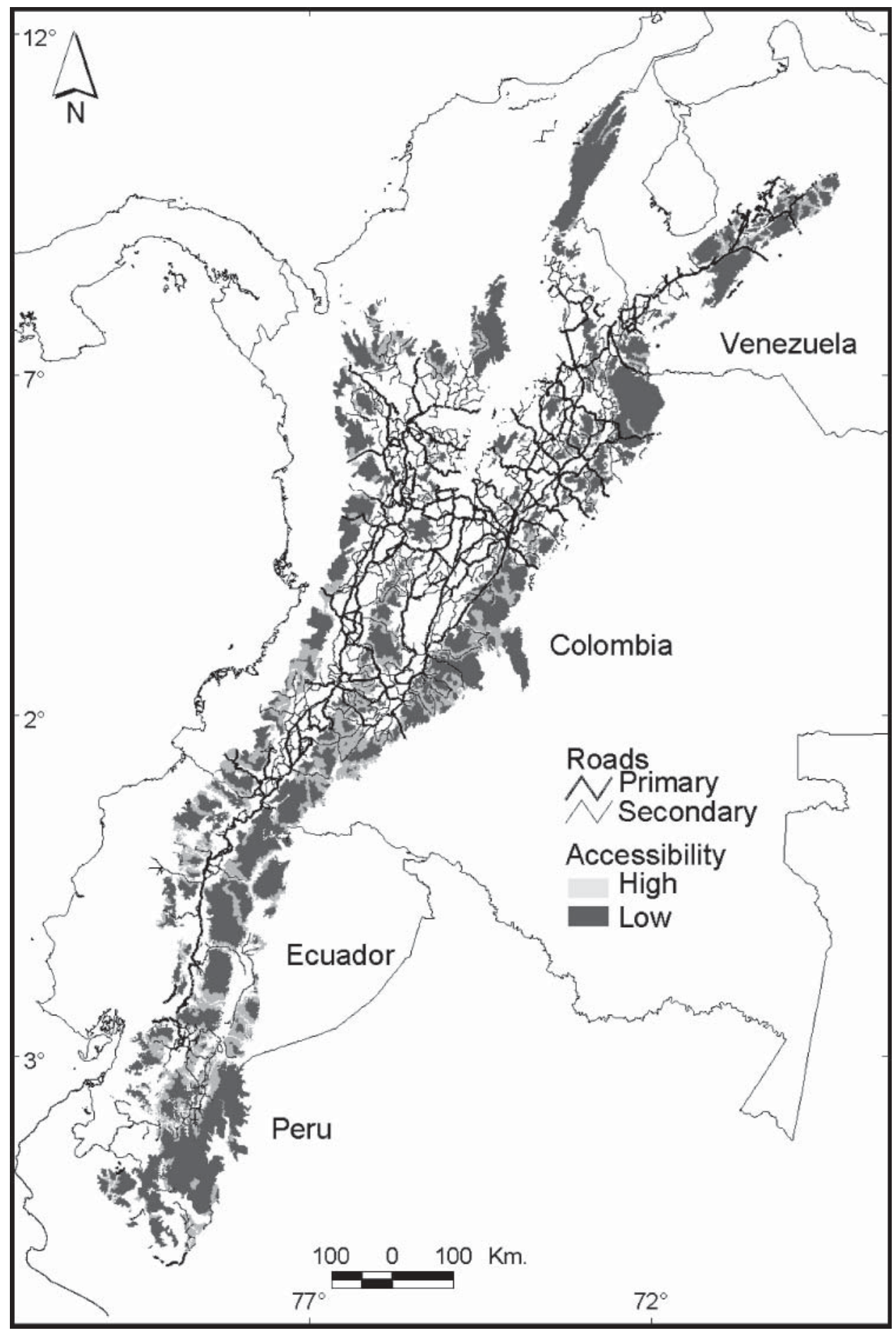

Fig. 3 The northern Andes, showing high and low accessibility areas for each bear habitat block (see text for details), and the road network.

palms (Euterpe spp., Prestoea spp.), and oak Quercus humboldtii acorns.

The temporal and spatial variability in resource availability probably forces bears to range over large areas, and they undertake altitudinal movements. The little evidence available suggests that bears use páramo during the dry season, when there is apparently little fruit available in the forest. When in páramo, bears rely heavily on bromeliads of the genus Puya, a pattern that has been documented throughout its range from Venezuela to Perú (Peyton, 1980; Rodriguez et al., 1986; Suárez, 1988; Goldstein \& Salas, 1993), but consumption 

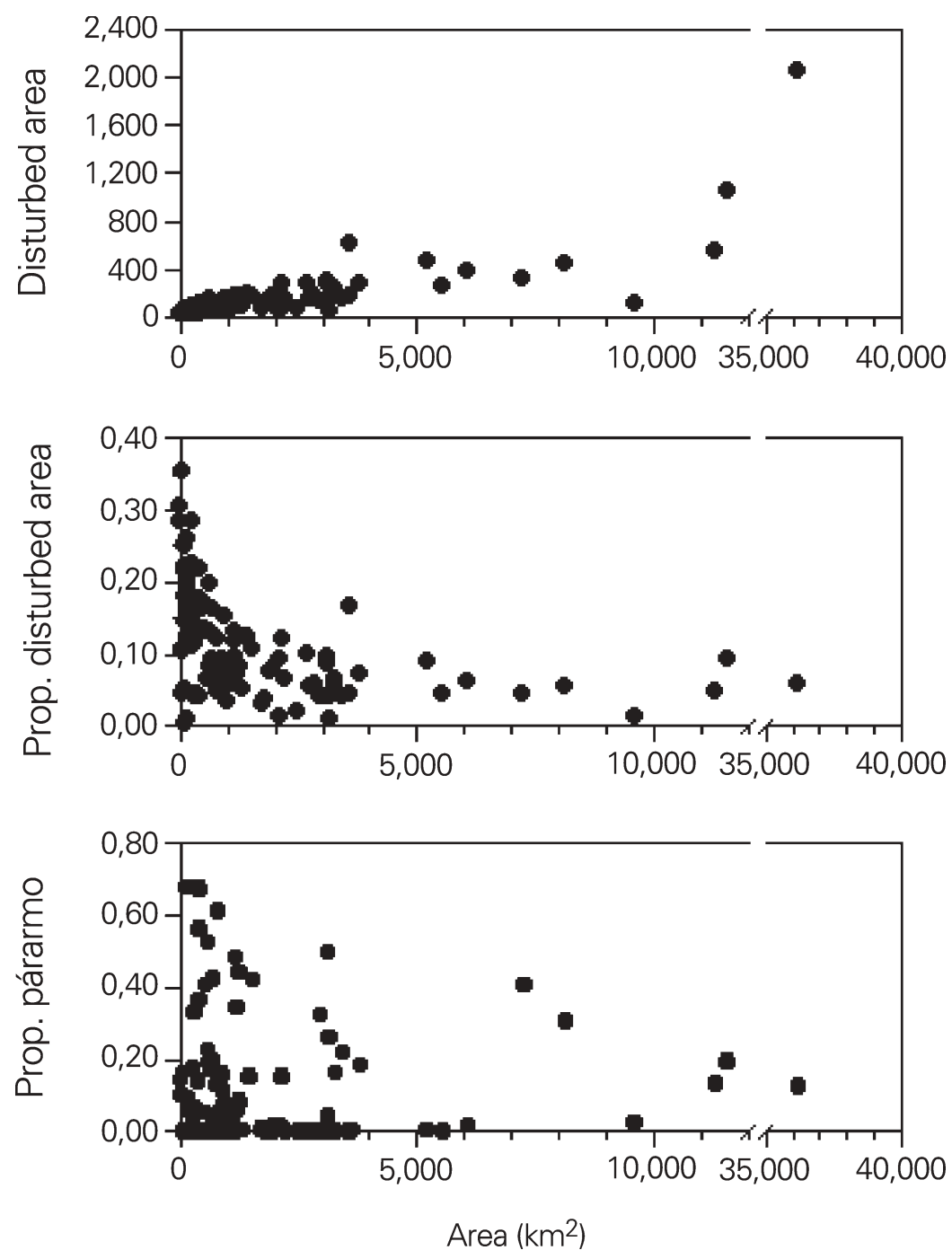

Fig. 4 Internal disturbed area, proportion of disturbed area, and proportion of area represented in páramo habitat, as a function of total area of 113 bear habitat blocks in the northern Andes.

of animal matter also apparently increases in an opportunistic fashion (Rodríguez et al., 1986; Suárez, 1988). The role of páramo in the persistence of bear populations, and what proportions of forest and páramo would make ideal bear habitat, are unknown. Does the absence of páramo mean that individual bears on the Pacific slope have larger home ranges, and thus larger areas of forest are needed to sustain populations? On the other hand, these populations have access to forest at lower elevations, but we do not know if this provides the bears with more suitable habitats. Circumstantial evidence suggests that bears on the Pacific slope concentrate in the low and mid-elevations when there is massive fruiting of some palms (A. Cortés, per. comm.).

Fragmentation along altitudinal gradients is probably the most limiting factor for bear populations in the inter-Andean slopes. Many of these areas also have proportionately more páramo than forest (Fig. 4), a combination that is not likely to be suitable for bears. Páramo might be an important seasonal habitat, but it is unlikely that a population can survive with little forest. Food resources in forest, such as lauraceous and palm fruits, are probably of higher quality than vegetative plant tissues. The Lauraceae are more diverse and abundant in mid- and high-elevation forest (1,500-3,000), while palms are more diverse and abundant at low to mid elevations (500-2,000 m). In some cases palms tend to form relatively large, monospecific stands, where food might be seasonally abundant. Oaks, which also form monospecific stands, mast in supra-annual cycles. Patterns of massive fruiting of these species probably determine bear movement patterns on a regional scale.

If bears do not have access to these resources, they may be forced to spend more time in páramo. One drawback 


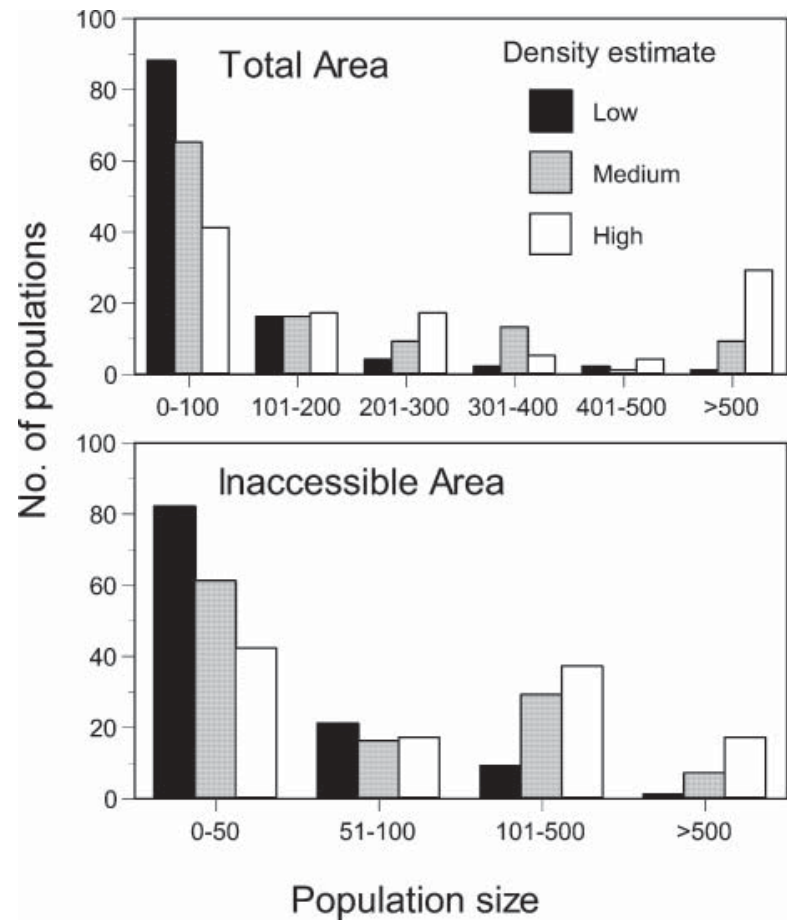

Fig. 5 Frequency distribution of number of bear populations as a function of estimated population size classes, for both total area of the habitat block and inaccessible area, calculated using high, medium and low population density estimates (see text for details).

of páramo is that, because it is an open ecosystem with no tree cover, bears may be more vulnerable to hunting. Thus, if they are forced to use páramo because there is not enough forest available, hunting pressure may increase. Elucidating the nature of altitudinal movements in spectacled bears is important not only for understanding their seasonal resource requirements, but for more precisely estimating population densities and predicting their responses and vulnerabilities to different landscape configurations.

The establishment of corridors to connect populations along the Andes has been suggested as a measure to counteract the effects of fragmentation (Yerena, 1994). However, it is not clear what type of movement will occur along these corridors. The type of movement (dispersal of juveniles, movement of adults within home ranges, or seasonal migration) each has different implications for a corridor. For example, if adult males and females establish home ranges in corridors, this may restrict the movement of other individuals through the area, and create a structure of source and sink populations, depending on habitat qualities. If only juveniles disperse through corridors, a metapopulation structure may result (Kattan \& Murcia, 2003). These types of population structures would have different management implications, and the design of any system of corridors needs to take into account how the regional population structure will change. Another aspect that needs to be considered is that, because of the configuration of the mountains and of the presence of human settlements, most corridors would be across páramo. This would force animals, in particular juveniles, to use a habitat where they are more vulnerable.

Establishing corridors to connect most fragments, particularly in the Colombian and Ecuadorian Andes, is in many areas unrealistic because of the presence of major roads and urban areas. What are, then, the alternatives for spectacled bear conservation in the northern Andes? Although no reliable estimates of hunting levels are available, recent data suggest that in some areas up to 10 bears might be killed per year $(\mathrm{H}$. Restrepo \& I. Goldstein, unpublished data). This suggests that there are two major limitations to the viability of bear populations: population size and human-caused mortality. Thus, the most effective actions would be to increase population sizes and decrease hunting levels. The effectiveness of these actions, however, depends on where they are carried out; increasing carrying capacity might effectively decrease extinction probability in source populations but not in sinks (Ferreras et al., 2001). Thus, a regional spectacled bear conservation strategy should first focus efforts on identifying areas where a combination of habitat protection and landscape management could realistically maintain large populations (either continuous or with a metapopulation structure; Ferreras et al., 2001). The best candidate regions for this approach are the Mérida Andes in Venezuela, the eastern slope of the Andes in Colombia and Ecuador, and the Pacific versant of Colombia, where there is a confluence of existing natural parks and habitat availability, with little human colonization. In areas where it is not realistic to increase population sizes because there is no habitat available, the best approach would be to decrease human-bear conflicts, thus reducing or eliminating humancaused mortality.

Any spectacled bear conservation strategy should take into account not only the bear's vulnerabilities, but its potential as an umbrella and charismatic species as well. As a landscape species, the bear can be used as a tool to design conservation landscapes that take into account its habitat and resource requirements, and the interaction with human landscapes (Sanderson et al., 2002). For example, the bear's requirement for continuous habitat along altitudinal gradients and over large areas could provide guidelines for the preservation and management of entire watersheds. This way, the bear would function as an umbrella for the protection of entire, ecologically functional biotas (Kattan \& Alvarez-López, 1996). Preserving bears in multiple-use landscapes, however, will increase the probability of conflicts with humans, and the causes and consequences of these conflicts, as well as the management options, need to be well understood. 
Finally, the bear's potential as a charismatic species for public education and political support should be an important part of any conservation strategy.

\section{Acknowledgements}

We thank WWF-Colombia and the Northern Andes Ecoregional Complex Project for allowing the use of maps and technical facilities. We also thank the International Centre for Tropical Agriculture for permission to use the accessibility model.

\section{References}

Duellman, W.E. (1999) Distribution patterns of amphibians in South America. In Patterns of Distribution of Amphibians. A Global Perspective (ed. W.E. Duellman), pp. 255-328. Johns Hopkins University Press, Baltimore, USA.

Ferreras, P., Gaona, P., Palomares, F. \& Delibes, M. (2001) Restore habitat or reduce mortality? Implications from a population viability analysis of the Iberian lynx. Animal Conservation, 4, 265-274.

Garshelis, D.L., Joshi, A.R., Smith, J.L.D. \& Rice, C.G. (1999) Sloth bear conservation action plan (Helarctos malayanus). In Bears. Status Survey and Conservation Action Plan (eds C. Servheen, S. Herrero \& B. Peyton), pp. 225-240. IUCN/ SSC Bear and Polar Bear Specialist Groups, IUCN, Gland, Switzerland.

Goldstein, I. (1991) Spectacled bear predation and feeding behavior on livestock in Venezuela. Studies on Neotropical Fauna and Environment, 26, 231-235.

Goldstein, I. \& Salas, L. (1993) Patrón de explotación de Puya sp. (Bromeliaceae) por Tremarctos ornatus (Ursidae) en el páramo El Tambor, Venezuela. Ecotropicos, 6, 1-9.

Kattan, G.H. (2000) Appendix A: Ecoregional patterns of diversity in the northern Andes. In Biodiversity Vision for the Northern Andes Ecoregional Complex.

Http:/ /www.wwf.org.co/andes/paginas/ que-es-el-cean.php [accessed 5 December 2003].

Kattan, G.H. \& Alvarez-López, H. (1996) Preservation and management of biodiversity in fragmented landscapes in the Colombian Andes. In Forest Patches in Tropical Landscapes (eds J. Schelhas \& R. Greenberg), pp. 3-18. Island Press, Washington, DC, USA.

Kattan, G.H. \& Murcia, C. (2003) A review and synthesis of conceptual frameworks for the study of forest fragmentation. In How Landscapes Change: Human Disturbance and Ecosystem Fragmentation in the Americas (eds G.A. Bradshaw \& P.A. Marquet), pp. 183-200. Springer-Verlag, Heidelberg, Germany.

Mace, R.D. \& Waller, J.S. (1998) Demography and population trend of grizzly bears in the Swan Mountains, Montana. Conservation Biology, 12, 1005-1016.

Pelton, M.R., Coley, A.B., Eason, T.S., Martinez, D.L.D., Pederson, J.A., van Manem, F.T. \& Weaver, K.M. (1999) American black bear conservation action plan (Ursus americanus). In Bears. Status Survey and Conservation Action Plan (eds C. Servheen, S. Herrero \& B. Peyton), pp. 144-156. IUCN/SSC Bear and Polar Bear Specialist Groups, IUCN, Gland, Switzerland.

Peyton, B. (1980) Ecology, distribution, and food habits of spectacled bears, Tremarctos ornatus, in Peru. Journal of Mammalogy, 61, 639-652.
Peyton, B. (1986) A method for determining habitat components of the spectacled bear (Tremarctos ornatus). Vida Silvestre Neotropical, 1, 68-78.

Peyton, B. (1999) Spectacled bear conservation action plan (Tremarctos ornatus). In Bears. Status Survey and Conservation Action Plan (eds C. Servheen, S. Herrero \& B. Peyton), pp. 157-164. IUCN/SSC Bear and Polar Bear Specialist Groups, IUCN, Gland, Switzerland.

Peyton, B., Yerena, E., Rumiz, D.I., Jorgenson, J. \& Orejuela, J.E. (1998) Status of wild Andean bears and policies for their management. Ursus, 10, 87-100.

Powell, R.A., Zimmerman, J.W., Seaman, D.E. \& Gilliam, J. F. (1996) Demographic analyses of a hunted black bear population with access to a refuge. Conservation Biology, 10, 224-234.

Rodríguez, D. (1991) Evaluación y uso del hábitat natural del oso andino Tremarctos ornatus (F. Cuvier, 1825) y un diagnóstico del estado actual de la subpoblación del Parque Nacional Natural Las Orquídeas. BSc thesis, Universidad Nacional de Colombia, Colombia.

Rodríguez, D., Poveda, J., Rivera, D., Sānchez, J., Jaimes, V. \& Lozada, R. (1986) Reconocimiento preliminar del hábitat natural del oso andino Tremarctos ornatus (F. Cuvier, 1825) y un diagnóstico del estado actual de la subpoblación del Parque Nacional Natural El Cocuy. Boletín Divulgativo Manaba No. 1. Universidad Nacional, Bogotá, Colombia.

Sanderson, E.W., Redford, K.H., Vedder, A., Coppolillo, P.B. \& Ward, S.E. (2002) A conceptual model for conservation planning based on landscape species requirements. Landscape and Urban Planning, 58, 41-56.

Sandoval, S. (2000) Dieta y uso del hábitat por parte del oso andino en la Reserva Natural La Planada, Nariño. BSc thesis, Pontificia Universidad Javeriana, Colombia.

Suárez, L. (1988) Seasonal distribution and food habits of spectacled bears Tremarctos ornatus in the highlands of Ecuador. Studies on Neotropical Fauna and Environment, 23, 133-136.

Woodroffe, R. \& Ginsberg, J.R. (1998) Edge effects and the extinction of populations inside protected areas. Science, 280, 2126-2128

WWF (2000) Biodiversity Vision for the Northern Andes Ecoregional Complex. Http:/ /www.wwf.org.co/andes/ paginas/que-es-el-cean.php [accessed 5 December 2003]. Yerena, E. (1994) Corredores ecológicos en los Andes de Venezuela. Parques Nacionales y Conservación Ambiental, Caracas, Venezuela.

\section{Biographical sketches}

Gustavo Kattan, Vladimir Rojas and Carolina Gómez share an interest in studying threatened species and the effects of habitat fragmentation, particularly in the northern Andes.

Olga Lucía Hernāndez is a GIS analyst and conservation strategist, with an interest in threatened species.

Isaac Goldstein and Francisco Cuesta devote their efforts to studying and protecting spectacled bears and their habitat.

Oscar Murillo is an ecologist with research interests in biogeography and population ecology.

Héctor Restrepo develops conservation strategies for national parks and threatened species. 